\title{
Effectuation theoretical debate: systematic review and research agenda
}

\author{
Suzi Elen Ferreira Dias and Edson Sadao lizuka \\ Centro Universitário da FEI, São Paulo, Brazil, and \\ Eduardo Pinto Vilas Boas \\ Escola Superior de Empreendedorismo, São Paulo, Brazil and \\ Escola Superior de Administração e Gestão, Santo André, Brazil
}

Effectuation theoretical debate

\begin{abstract}
Purpose - The purpose of this paper is to understand the theoretical discussion of effectuation since the seminal paper in 2001 and to propose an agenda for future studies.

Design/methodology/approach - Systematic literature review and content analysis of 71 papers.

Findings - Most papers performed a replication of the concepts empirically, and few studies proposed to understand theoretical aspects of effectuation, among them, some authors presented theoretical advances to improve the approach and others participated in an ongoing debate that shows there is no consensus on whether the approach is theory or if considered, appears to be under construction at a rudimentary level or being questioned.
\end{abstract}

Research limitations/implications - The method requires authors to make choices, so the database used and the criteria defined for searching papers that were analyzed are the main limitations of this research.

Practical implications - The authors suggest that researchers, teachers and practitioners use effectuation analytically and reflectively.

Social implications - The authors present and analyze the current theoretical debate on effectuation. Results suggest the need for new discussions about the concepts, as well as new theoretical efforts of the researchers to analyze the potentialities and limitations of this approach.

Originality/value - Among empirical and applied research, with replications of the concepts of effectuation, this research contributes to a theoretical discussion based on a systematic literature review, seeking to bring new reflections about this approach. Additionally, the authors present an agenda of theoretical gaps for the development of future research.

Keywords Literature review, Academic production, Effectuation limitations, Research agenda

Paper type Literature review

\section{Introduction}

The seminal work on effectuation (effectual logic) resulted from Saras Sarasvathy's doctoral dissertation in 1999, in which, comparing a group of bank managers and entrepreneurs, the

(C) Suzi Elen Ferreira Dias, Edson Sadao Iizuka and Eduardo Pinto Vilas Boas. Published in Innovation and Management Review. Published by Emerald Publishing Limited. This article is published under the Creative Commons Attribution (CC BY 4.0) licence. Anyone may reproduce, distribute, translate and create derivative works of this article (for both commercial and noncommercial purposes), subject to full attribution to the original publication and authors. The full terms of this licence may be seen at http://creativecommons.org/licences/by/4.0/legalcode

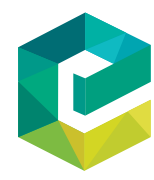

Innovation \& Management Review Vol. 17 No. 1,2020 pp. $41-57$

Emerald Publishing Limited $2515-896$ 
INMR

17,1

author analyzed the differences in the decision process during the hypothetical construction of a company (Sarasvathy, 2001). From the results found, the author proposed a new look at the way entrepreneurs make choices and decisions.

Given the premise of market uncertainty, it is impossible or, at least, difficult to make estimates for business. Thus, entrepreneurs focus on the logic of control. At that time she termed the approach as a "rudimentary theory of processes in business" as opposed to the existing traditional decision model, causation (or causal logic), in which decision processes focus on forecasting logic through estimates (e.g. costs and expected returns) that support decision-making (Sarasvathy, 2001, p. 249).

Over time, researchers have devoted themselves to the theoretical and empirical understanding of effectuation. In this context, Read, Song and Smit (2009) and Werhahn et al. (2015) worked on building quantitative models from empirical foundations of organizations. On the other hand, Perry, Chandler , and Markova (2012), Ghorbel and Boujelbène (2013), Pawêta (2016) and Matalamäki (2017) devoted their attention to understanding effectuation's academic production by focusing on specific topics such as understanding in the corporate environment or the field of international entrepreneurship.

Previous studies have focused on the replications of the effectuation principles. Therefore, articles with a theoretical and analytical perspective are less frequent. Furthermore, they have not understood the theoretical perspective analytically and systematically.

Given this, this article aims to fill this gap, that is, to understand the theoretical discussion about effectuation, since the seminal article in 2001 and to propose a research agenda for future studies. For this, we investigate the following research questions:

$R Q 1$. From the seminal article, what is the current state of the theoretical debate on effectuation?

$R Q 2$. What were the academic researchers' efforts to understand, analyze or construct the concepts of effectuation?

RQ3. What are the theoretical gaps for future studies? To answer these questions we started with a systematic literature review to understand the research opportunities.

This investigation contributes to the advancement of knowledge through the presentation, consolidation and analysis of the theoretical discussion about effectuation that indicates the need for new reflections and academic debates around the concepts. Additionally, it offers some provocation so that studies can go beyond mere empirical replication and additional theoretical efforts. Some researchers indicate the need to question effectuation as a theory, and others indicate that the concepts presented need further explanation and are insufficient to explain the phenomenon. Moreover, this research encourages researchers, professors and practitioners to seek to use effectuation analytically and reflexively.

\section{Effectuation review: previous studies}

To address the existing research gaps, as a first step, we sought to understand the academic production of effectuation. We do this by analyzing the studies that conducted a review of the theme.

For this, we used the Publish or Perish software version 5 because it has an interface to different databases. We searched for articles that contained the terms "effectuation and review" in the titles; also, "effectuation or effectual" in the title and "extensive literature review" or "systematic literature review" or "systematized literature review" in the full text. 
We found 28 documents published between 2001 and September 2017. We then apply a filter based on the 2016 Journal Citation Reports (JCR) index, equal to or greater than one, to analyze qualified studies and peer-reviewed articles from the Business and Management areas.

We found six academic articles that met these criteria, being four systematic reviews on effectuation, one meta-analysis, and one concept review, development and scale validation study. Thus, since the seminal article in 2001, only four studies have proposed to understand the academic production of effectuation through studies of systematic literature review.

Among these studies, Perry et al. (2012) focused on understanding the empirical studies about effectuation. The authors concluded that the research is in the transition to an intermediate stage. Additionally, the authors acknowledged that effectuation helps to understand entrepreneurship, but there is a need for more empirical testing, so the authors offer a research agenda for rigorous further studies.

Ghorbel and Boujelbène (2013) classified and summarized relevant research on effectuation and suggested directions for future studies. The authors stated that entrepreneurs differ from managers because they use effectual logic and suggested more empirical research, as well as analysis of the theoretical aspects of the approach.

Pawêta (2016) systematized the international entrepreneurship literature with an interface with effectuation and found that they recognize the use of different causal and effectual logic. Thus, the author indicated the need for future empirical studies to analyze the intersection of effectuation and international entrepreneurship.

Finally, Matalamäki (2017) investigated the theoretical stage of development of the approach. The author found that effectuation studies are related to four types of themes such as innovation and product development, internationalization, effectuation and causation simultaneously and entrepreneurial expertise. Furthermore, the author also indicated that the approach is in an intermediate stage of development and that there is an inconclusive "battle" between convergent and divergent groups of researchers involved in a scientific debate on the concepts of effectuation, but not deepening in the theoretical discussion, it only indicates the need for further research to understand these issues on the subject better. Table I summarizes the analysis of these studies.

Therefore, since the seminal article published in 2001, different authors have carried out systematic review studies, but none of them aimed to understand the theoretical discussion about effectuation. That is, this is the central gap detected and the purpose of this research.

\section{Methodological procedures}

This article applies a qualitative methodology of systematic literature review that involves rigorous criteria from a comprehensive and unbiased search (Tranfield, Denyer, \& Smart, 2003; Cronin, Ryan, \& Coughlan, 2008). This procedure allows the reduction of biases and increases the reliability of the research results, besides providing a relevant synthesis of the state of the art of the phenomenon (Tranfield et al., 2003; Cronin et al., 2008; Gough, Oliver, \& Thomas, 2017).

In general, the structured review process consists of three phases: data collection, data analysis and synthesis. Scientific accuracy is required to achieve a quality review (Briner \& Denyer, 2012).

In the stage of data collection, we defined the criteria for searching the articles Harzing \& Van der Wal (2008) observed that in general, systematic literature reviews are made using the Web of Science database . However, the authors suggested the use of Google Scholar because it is free and allows searching in different databases. There is no evidence of

Effectuation theoretical debate 


\section{INMR}

17,1

\begin{tabular}{lll}
\hline Authors & Objective & Study \\
\hline Perry et al. & Review the literature on & Systematic literature \\
(2012) & effectuation and propose & review \\
& to conduct rigorous & (29 papers) \\
& future empirical studies &
\end{tabular}

\section{4}

Ghorbel and

Boujelbène

(2013)

Pawêta (2016)

Matalamäki (2017)

Read, Song, and Smit (2009)

Werhahn et al. (2015)
Classify and summarize relevant research and identify future directions

Systematize the literature of international entrepreneurship with interface with effectuation

Investigate the theoretical development stage of effectuation

Measure the relationship between effectual principles and the performance of new ventures

Develop the concept and propose a scale for measuring the level of effectual guidance
Systematic literature review (122 papers)

Systematic literature review (94 papers)

Systematic literature review (81 papers)

Meta-analysis (9,897 companies)

Extensive literature review, scale development and validation $(1,837$ companies)
Main findings

Research is in the transition to an intermediate stage

Effectuation helps to understand entrepreneurship but there are few empirical tests, despite having a theoretical model

The authors propose a research agenda for rigorous empirical studies

Entrepreneurs differ from managers because they use effectual logic

Researchers should develop more empirical research, as well as theoretical analysis

Both works of literature recognize the use of different causal and effectual logic

Future empirical studies need to analyze the intersection of effectuation and international entrepreneurship

There are four types of related themes: innovation and product development; internationalization; effectuation and causation simultaneously; and entrepreneurial expertise. There is an inconclusive "battle" with different points pointed out by the researchers

The authors review the concepts of effectuation principles

Performance is positively related to "what I know," "who I am" and "whom I know"

Through an extensive literature review, the authors define the concept of effectual orientation from a strategic perspective The authors develop a multidimensional model that measures effectual orientation

Table I.

Effectuation review studies

Source: By the authors

differences between Google Scholar, Web of Science and Scopus (De Winter, Zadpoor, \& Dodou, 2014; Martín-Martín, Orduna-Malea, Thelwall, \& López-Cózar, 2018). These authors also recognized that documents cited in Google Scholar are necessarily a collection of Web of Science, Scopus and other databases. 
Therefore, in this research, we chose to use Publish or Perish software version 5 with Google Scholar interface as a reliable and plausible means of investigation due to its accessibility and breadth of the search for articles (Harzing, 2011).

The next step was the selection of keywords that needed to be "carefully considered" to search the articles in the databases (Cronin, Ryan \& Coughlan, 2008, p. 40). We tested different possibilities based on the data accessibility offered by the search engine. After numerous tests, knowing that Sarasvathy's (2001) seminal article uses the term "theory of effectuation" and given the purpose of this study to understand the theoretical discussion on the subject, we chose to use two keywords for the search of articles: "effectuation theory" and "theory of effectuation." The publication period was between 2001 and September 12, 2017.

In this search, we found 1,188 documents (including articles, books, dissertations and theses). We have chosen to base only peer-reviewed scholarly studies published in journals qualified by the JCR 2016 impact factor equal to or greater than one, and areas of business and management. Thus, 127 articles were selected, already excluding those that appeared in duplicate (20 papers).

In the next step, we applied the content analysis technique, which assumes three steps:

(1) pre-analysis (material organization);

(2) material exploration (definition of analysis categories); and

(3) treatment of results through critical and reflexive analysis (Bardin, 2009).

This technique allows us to explore information in a structured way using qualitative databases (Cronin et al., 2008; Gaur \& Kumar, 2018; Haapanen \& Tapio, 2016) built from the collection of abstracts, main findings, conclusions and research gaps presented by the studies. For method validity, all authors read each article, taking into account the questions raised.

\section{Analysis and discussion of results}

The 71 articles analyzed are distributed in 28 journals, with 10 journals concentrating 65 per cent of the publications, which focused on entrepreneurship (6 journals published 32 articles) and management (4 journals published 13 articles), as can be seen in Table II.

We observed that 78 per cent of the authors engaged in empirical replication, either in the application of concepts or in support of explaining different phenomena. A small group of authors (15 articles) proposed to analyze and understand the theoretical aspects of effectuation, summarized in Table III.

From the studies that replicated concepts empirically, there is a group of authors who agree on simultaneity of the use of effectuation and causation. These studies address some situations that favor the choice between approaches. However, they do not offer an integrated analysis of under what aspects and under what conditions. Other studies only use effectuation as support to explain different phenomena. Finally, a small group of authors proposed to understand the theoretical aspects of effectuation.

\subsection{Research proposals to understand theoretical aspects of effectuation}

There are two different groups of authors who proposed to understand the theoretical features of effectuation. A group of authors who contributed with theoretical advances obtained results and directions for the improvement of the theory. Another group offered points for debates on the concepts of effectuation, some authors made criticism or pointed limitations to the approach and others make arguments in its defense.
Effectuation theoretical debate 


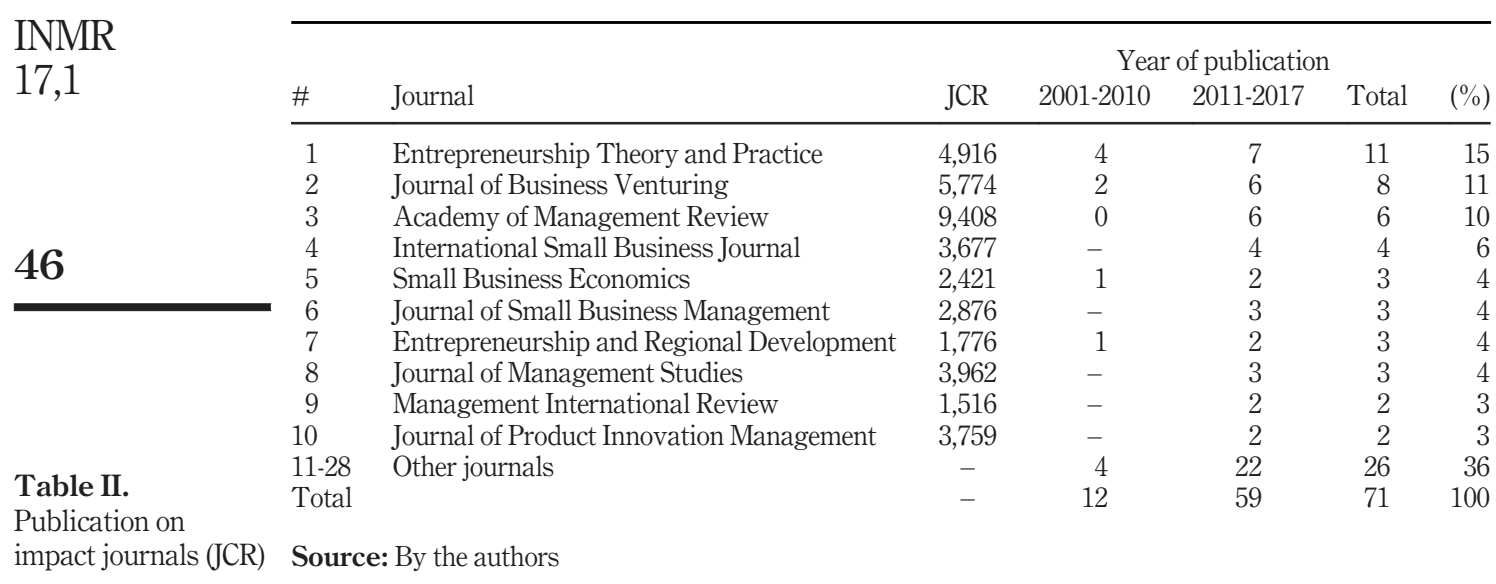

The first group of authors is responsible for three articles. In the first, Steyaert (2007) makes a 20-year analysis of entrepreneurial process theories. The authors approach effectuation based on practice, which tries to explain the entrepreneurs' way of acting, and promising in the field of entrepreneurship due to being a creative process and different from existing ones.

In the second article, Fisher (2012) connects Bricolage with effectuation. The author presents commonalities; however, he does not explain the difference between the approaches. Additionally, he proposes that effectuation is abstractly described to entrepreneurs' understanding, suggesting that focusing on behaviors may help to clarify. It is necessary to identify when it is best to use each approach or even a combination of them.

In the last article of this group, Perry et al. (2012) make a bibliometric review of the publications that appeared between 1998 and 2012 on effectuation to verify the maturity of the theory. Thus, the authors point out that although there are several theoretical and empirical publications, the approach can still be considered as an incipient theory indicating directions for future studies.

The second group of authors is responsible for three theoretical debate articles, which present criticisms, limitations or defense arguments to effectuation. Goel and Karri (2006) start the first debate by proposing that entrepreneurial personality characteristics, combined with effectual logic, increase the chance of developing overconfidence, which may increase the company's risk. In response, Sarasvathy and Dew (2008b, p. 734) say that overconfidence has a relevant concept in causal logic. However, it is "largely irrelevant in effectual logic," knowing that entrepreneurs behave differently according to the approach used. Karri and Goel (2008, p. 746) then respond that Sarasvathy and Dew (2008b) approach "alternative behavioral assumptions" in an underdeveloped way and do not clarify how these points contest the arguments presented. Karri and Goel (2008, p. 746) conclude the article by reaffirming the initial position and saying that Sarasvathy and Dew (2008b) presented "assumptions that are restrictive and unnecessary for the advancement of effectuation theory and that these assumptions do not meet the parsimony criterion in the development of theory".

Chiles, Bluedorn, and Gupta (2007) start the second theoretical debate proposing the use of Lachmann's works by entrepreneurship authors. The authors state that Sarasvathy (2001) already uses the economist's ideas, but without direct reference to him. In response, 


\begin{tabular}{l} 
Categories \\
\hline Empirical replication or \\
support to explain other \\
phenomena \\
(56 papers)
\end{tabular}

Subcategories

Empirical effectuation replication in different business contexts (37 papers)
Authors

Concurrency between effectuation and causation General entrepreneurship: Sarasvathy \& Dew (2005), Chandler et al. (2011), Berends et al. (2014), Blauth, Mauer, and Brettel (2014), Agogué, Lundqvist \& Middleton (2015), Daniel et al. (2014), Guo, Cai, and Zhang (2016), Smolka et al. (2016) and Ortega (2017)

International entrepreneurship: Gabrielsson \& Gabrielsson (2013), Kalinic, Sarasvathy, and Forza (2014), Nummela et al. (2014), Galkina \& Chetty (2015), Laine \& Galkina (2017) and Yang \& Gabrielsson (2017)

New business creation: Reymen et al. (2015), Alsos et al. (2016) and Laskovaia, Shirokova, and Morris (2017)

Wiltbank et al. (2009), Fischer \& Reuber (2011), Gabrielsson \& Politis (2011), Brettel et al. (2012), Evers, Andersson, and Hannibal (2012), Nielsen \& Lassen (2012), Politis, Winborg, and Dahlstrand (2012), O'Connor \& Rice (2013), Sarasvathy et al. (2014); Lam \& Harker (2015), Werhahn et al. (2015), Akemu, Whiteman, and Kennedy (2016), Velu \& Jacob (2016), York, O'Neil, and Sarasvathy (2016), Cai et al. (2017), Chandra (2017), Engel et al. (2017), Futterer, Schmidt, and Heidenreich (2017) and Nemkova (2017)

Effectuation as support to Fiet, Piskounov, and Patel (2005), Mitchell et al. explain different phenomena (2007), Brinckmann, Grichnik, and Kapsa (2010), (19 papers)

Neck \& Greene (2011), Dacin, Dacin, and Tracey (2011), Sharma \& Salvato (2011), Lusch \& Vargo (2012), Watson (2013), Fayolle \& Liñán (2014), McCaffrey (2014), Pruthi (2014), Spedale \& Watson (2014), Selden \& Fletcher (2015), Knight \& Liesch (2016), Markman et al. (2016), Sieger et al. (2016), Korsgaard et al. (2016), Nowiński \& Rialp (2016) and Packard (2017)

Theoretical aspects (15 papers)

Theoretical advances (3 papers) Theoretical debate (12 papers) Steyaert (2007), Fisher (2012) and Perry et al. (2012)

Goel \& Karri (2006), Chiles, Gupta, and Bluedorn (2008), Chiles, Gupta, and Bluedorn (2008), Karri
Effectuation theoretical debate \& Goel (2008), Sarasvathy \& Dew (2008a, 2008b), Arend, Sarooghi, and Burkemper (2015), Garud \& Gehman (2016), Reuber, et al. (2016), Arend, Sarooghi \& Burkemper (2016), Read et al. (2016) and Gupta, Chiles, and McMullen (2016)

Table III. Categorization of results

Source: By the authors

Sarasvathy and Dew (2008a) disagree with the arguments and claim that the authors have different interpretations and perspectives on how effectuation works and its relationship with Lachmann. Finally, Chiles, Gupta and Bluedorn (2008) answer reaffirming the effectuation relationship with Lachmann's proposals and clarify some of their views. 
INMR

17,1

In the third theoretical debate, Arend, Sarooghi and Burkemper (2015) question effectuation as a theory by analyzing the concepts of structure experience, explain, and establish (3E). The authors conclude that effectuation is underdeveloped as a theory of entrepreneurship, as it does not meet the researcher's experience criteria through observation and literature review; explanation of the phenomenon; and establishment as to the viability and value of the theory. Moreover, they question novelties that effectuation, as for them many of the characteristics that describe phenomenon had already been presented in the entrepreneurship literature, thus they criticize non-recognition of previous works, including benefits of causation. From this study emerge four articles as answers to the arguments presented and a replica article by Arend et al. (2016).

Read et al. (2016) write the first article to defend effectuation in response to Arend et al. (2015). They do not agree with the arguments presented, classifying them as a positivist analysis. They state that the authors failed to analyze much of the existing literature. They present a table with the consolidation of previous studies to answer the three main criticisms: construction without connecting with previous studies, lack of empirical observations and lack of adoption by educators and practitioners. They also state that Arend et al. (2015) seek to understand the validity of effectuation when the most relevant is to understand the utility. Finally, the authors agree with Arend et al. (2015) that critical reflection on effectuation may indicate opportunities for empirical research and may even improve concepts. However, they disagree with the directions presented and indicate new opportunities for future studies.

In the next defense article, Reuber, Fischer and Coviello (2016) agree in part with the previous two articles. It means further theoretical advances are needed for effectuation to evolve into a theory. However, they believe that the criticism presented by Arend et al. (2015) should be more constructive and less destructive. For Reuber et al. (2016), the most important point would be to understand effectuation as an evolving theory, and from that to understand the concepts that are stable and consistent, as well as, which deserve to be improved.

Gupta, Chiles and McMullen (2016) reinforce the arguments of Read et al. (2016). They criticize the way effectuation was analyzed and claim that it should be viewed as a process theory, so it does not fit the analysis of 3Es by Arend et al. (2015).

Garud and Gehman (2016) follow another path of argument and present the same results as Gupta et al. (2016). The authors state that the 3E framework applied by Arend et al. (2015) should not be used to evaluate nonlinear theories with observations of complex processes or phenomena. Additionally, Garud and Gehman (2016) presented a literature review with studies that sought to understand how to evaluate theory and demonstrate that there is no consensus on this topic in the management area.

Finally, Arend, Sarooghi and Burkemper (2016) present a reply to Read et al. (2016) and other authors. They reaffirm the assumptions made in 2015 , and reinforce the validity of the arguments that were supported by previous studies that cite effectuation frequently. Furthermore, the authors refute the answers presented and reinforce their position regarding the use of the $3 \mathrm{E}$ framework. They claim that it is a robust theory evaluation tool that seeks to understand validity, but with great concern for pragmatism, so it applies to all theories.

Arend et al. (2016) explain that Read et al. (2016) present previous studies, but they neither explain the connection with previous theories nor how effectuation adds value to them. Additionally, most of these works consider effectuation as a logic, an approach, a construct, none consider it as a theory. None of these studies compared the approach with other modes of action; only one study proves the superiority of effectuation over causation 
(Arend et al.2016). The authors also reject the arguments presented by Read et al. (2016) about pedagogical adoption and popularity in the press, as they say that initial criticism was that effectuation did not add value to the student and understand that this point remains unexplained.

In response to Reuber et al. (2016), Arend et al. (2016) state that they recognize the evolution of effectuation and that structure $3 \mathrm{E}$ explicitly addresses the stabilization of constructs. Finally, Arend et al. (2016) state that Gupta et al. (2016) and Garud and Gehman (2016) do not offer evidence that effectuation fits the definition of process theory. However, the theoretical framework $3 \mathrm{E}$ is a theory assessment that can be applied to all valid observations, including complex observations and phenomena (Arend et al., 2016).

Arend et al. (2016) say that advocates of the effectuation theory were not open to suggestions and critics. They could have been more constructivist, better accepting criticism and understanding that the theoretical debate may contribute to the evolution of the theory. Advocates claim that effectuation is part of a new reality, when in fact there is no consensus on what this new reality is. Additionally, they state that the $3 \mathrm{E}$ framework is not suitable for evaluation without offering a set of alternative criteria proving that it is a theory (Arend et al., 2016).

The analysis of the theoretical debates shows three different prisms on effectuation:

- Authors who understand that effectuation offers theoretical contributions but have limitations in some respects (Chiles et al., 2008, 2007; Goel \& Karri, 2006; Karri \& Goel, 2008; Reuber et al., 2016);

- Most critical authors who question effectuation as theory (Arend et al., 2016, 2015); and

- Authors who present arguments in defense of effectuation (Garud \& Gehman, 2016; Gupta et al., 2016; Read et al., 2016; Sarasvathy \& Dew, 2008a, 2008b).

Therefore, after more than a decade and a half and publication of different articles, the debate on effectuation remains open and inconclusive (Matalamäki, 2017). The authors who presented a critical analysis for the approach understand that different arguments presented remain unexplained and that the defenders of it seem to be closed to debate.

\section{Final remarks}

The systematic literature review indicates that since the proposition of effectuation in 2001, there has been a predominance of studies that seek to test effectuation empirically, either through the replication of concepts (Arend et al., 2015) or to help explain other phenomena.

In this sense, few studies have proposed to analyze effectuation from the theoretical point of view, as a small group sought to understand conceptual aspects and contributed with theoretical advances to improve the approach.

A second small group of authors participated in theoretical debates that remain inconclusive, with different positions among the authors.

In this regard, some authors understand effectuation as a theory but have conceptual limitations. A more critical article questions effectuation as theory (Arend et al., 2015). Finally, a group of authors presents arguments in defense of the approach, responding to the criticisms and limitations presented.

Effectuation theoretical debate $\longrightarrow$ 
INMR

17,1
The criticisms or limitations are related to the foundations on which effectuation was built (Arend et al., 2015; Chiles et al., 2008; Karri \& Goel, 2008) and even to the elements that make it a theory (Arend et al., 2015). Furthermore, if effectuation is a pragmatic theory, it has to be effective in practice, but so far there are not enough empirical elements to demonstrate its practical implications (Arend et al., 2015).

Another limitation indicates that effectuation is very focused on the individual level and little concerned with the level of the organization (Werhahn et al., 2015). Some authors even say that some effectuation points are subjective, which can make it difficult for entrepreneurs to understand (Fisher, 2012).

The theoretical debate on effectuation remains open, which indicates that the approach is open to discussion. Furthermore, it is worth mentioning that part of the authors who proposed to criticize the concepts of effectuation felt that the arguments presented were not answered and that the advocates of the approach are closed to the debate. This seems to indicate the lack of interest in theoretical and critical debate, and this kind of posture tends to limit theoretical advance.

Therefore, this study shows that there is no consensus on effectuation being theory or not. If considered a theory, it appears to be under construction, at a rudimentary level and it is being questioned. It is necessary to carry out further studies focusing on theoretical aspects.

\subsection{Study limitations and future research agenda}

The systematic literature review method with the content analysis technique requires the authors' choices to select a base of studies that can be thoroughly analyzed to answer the research objective. Thus, article base selected has limitations due to the choice and selection of the database, as well as the search criteria applied.

The authors participating in the debate addressed some theoretical gaps for future studies. Despite the differences of opinion, some authors present the same directions. It is necessary to understand the conditions that favor the simultaneity of effectuation and causation (Fisher, 2012; Read et al., 2016). It is also relevant to understand who the effectuators are, as well as their competencies (Arend et al., 2015; Read et al., 2016). Table IV presents a summary of all the points presented by the authors.

Theoretical debates are essential for knowledge evolution, so we suggest that future studies return discussions about the approach. One way is to understand if effectuation is theory or not, as well as what it takes to be theory and what stage it is. To do this, some articles in management may be helpful (Corley \& Gioia, 2011; Weick, 1995; Whetten, 1989). Furthermore, we suggest other opportunities for the search agenda:

- Empirical studies with analysis of theoretical concepts. We indicate that further studies go beyond a test of replication of concepts in different contexts, as indicated by Arend et al. $(2015,2016)$ and Ghorbel and Boujelbène (2013). In this regard, few studies have sought to understand the functionality and application of effectuation principles in the practice of entrepreneurs in different scenarios, so it is interesting to investigate this point. Moreover, some researchers note subjectivism in understanding some of the concepts and principles of effectuation (Arend et al., 2015; Fisher, 2012), does it need to define the level of entrepreneurs that apply or make it more detailed in terms of organization (Werhahn et al., 2015)?

- Many authors have indicated the simultaneity between causation and effectuation (Ferreira et al., 2017; Laine \& Galkina, 2017; Laskovaia et al., 2017; Ortega, García, \& Santos, 2017; Yang \& Gabrielsson, 2017; Guo et al., 2016; Smolka et al., 2016). 


\begin{tabular}{|c|c|c|c|}
\hline Category & Authors & Theoretical gaps & ctuatio \\
\hline \multirow[t]{3}{*}{$\begin{array}{l}\text { Theoretical } \\
\text { advances }\end{array}$} & Steyaert (2007) & $\begin{array}{l}\text { Study entrepreneurship from the perspective of other process } \\
\text { theories or seek to explain it from the perspective of theories } \\
\text { presented by the author }\end{array}$ & dehate \\
\hline & Fisher (2012) & $\begin{array}{l}\text { Identify when it is best to use effectuation, causation or the best } \\
\text { combination of approaches }\end{array}$ & \\
\hline & Perry et al. (2012) & $\begin{array}{l}\text { The authors suggest new types of questions, data collection } \\
\text { methods, units of analysis and theoretical contributions }\end{array}$ & 51 \\
\hline \multirow[t]{7}{*}{$\begin{array}{l}\text { Theoretical } \\
\text { debate }\end{array}$} & Goel and Karri (2006) & $\begin{array}{l}\text { Understand which elements of effectual logic have the most } \\
\text { significant effect on overconfidence }\end{array}$ & \\
\hline & Chiles, Gupta, and & Understand effectuation based on Lachmann's thinking. Explore the & \\
\hline & Bluedorn (2008) & $\begin{array}{l}\text { Lachmannian view on entrepreneurship, for example, creating and } \\
\text { exploiting opportunities }\end{array}$ & \\
\hline & $\begin{array}{l}\text { Arend, Sarooghi, and } \\
\text { Burkemper (2015) }\end{array}$ & $\begin{array}{l}\text { Five ways as follows: explain the causes and effects of effectuation; } \\
\text { explore performance influences or redefine boundaries; improve } \\
\text { problem definition accuracy and understand benefits and risks; } \\
\text { explain the differences regarding concepts similar to effectuation, } \\
\text { existing in the literature before the seminal article; and understand } \\
\text { who the effectuators are, how, when they applied, what worked, } \\
\text { what went wrong, and how their skills improve }\end{array}$ & \\
\hline & Read et al. (2016) & $\begin{array}{l}\text { Seven ways as follows: differentiate control as strategy and } \\
\text { outcome; identify the effective skills of entrepreneurs; conditions } \\
\text { that favor the use of logic and the ways of alternating or combining; } \\
\text { connect with planning, negotiation and goal setting; integrate with } \\
\text { interconnectedness of changing and evolving selection; explain how } \\
\text { to turn media into resources; and understand more about co-creative } \\
\text { equity relationships in partnerships }\end{array}$ & \\
\hline & Reuber et al. (2016) & $\begin{array}{l}\text { Understand the integration between creativity (effectual) and habit } \\
\text { (causal) of entrepreneurs, recognizing that they are complementary } \\
\text { and not different processes. Understand how and under what } \\
\text { conditions the usual patterns, even if they occur in a hybrid way }\end{array}$ & \\
\hline & $\begin{array}{l}\text { Gupta, Chiles, and } \\
\text { McMullen (2016) }\end{array}$ & $\begin{array}{l}\text { Examine effectuation to understand characteristics, motive, and } \\
\text { how events happen over time }\end{array}$ & $\begin{array}{l}\text { Table IV. } \\
\text { Theoretical gaps for }\end{array}$ \\
\hline \multicolumn{3}{|c|}{ Source: By the authors } & \\
\hline
\end{tabular}

However, there is no consensus on which aspects and under which conditions are more appropriate to choose one approach over another, so we recommend that future studies explore these issues, including seeking to understand the coexistence between approaches (Read et al., 2016; Fisher, 2012); and

- Some authors had already explored the nonlinear decision-making process (Behn, 1988; Cohen et al., 1972; Weick, 1995), so new studies can understand the interface between approaches, as well as similarities, convergences and divergences.

The possibilities for theoretical research on effectuation do not end with these suggestions. On the contrary, the research undertaken reinforces the arguments surrounding the inconclusiveness of whether effectuation is a theory. More clarity is needed on the conceptual boundaries and possible limitations of this proposition. Finally, there seems to be a long way to go for researchers working in the field of entrepreneurship. 
INMR

17,1

Akemu, O., Whiteman, G., \& Kennedy, S. (2016). Social enterprise emergence from social movement activism: the fair phone case. Journal of Management Studies, 53, 846-877. Retrieved from https://doi.org/10.1111/joms.12208

Alsos, G. A., Clausen, T. H., Hytti, U., \& Solvoll, S. (2016). Entrepreneurs' social identity and the preference of causal and effectual behaviours in start-up processes. Entrepreneurship \& Regional Development, 28, 234-258. Retrieved from https://doi.org/ 10.1080/08985626.2016.1155742

Arend, R. J., Sarooghi, H., \& Burkemper, A. (2015). Effectuation as ineffectual? Applying the 3e theoryassessment framework to a proposed new theory of entrepreneurship. Academy of Management Review, 40, 630-651. Retrieved from https://doi.org/10.5465/amr.2014.0455

Arend, R. J., Sarooghi, H., \& Burkemper, A. C. (2016). Effectuation, not being pragmatic or process theorizing, remains ineffectual: Responding to the commentaries. Academy of Management Review, 41, 549-556. Retrieved from https://doi.org/10.5465/amr.2016.0086

Bardin, L. (2009). Análise de conteúdo. 4. edição revisada e atualizada, Lisboa: Edições 70.

Behn, R. D. (1988). Management by groping along. Journal of Policy Analysis and Management, 7, 643663. Retrieved from https://doi.org/10.2307/3323485.

Berends, H., Jelinek, M., Reymen, I., \& Stultiëns, R. (2014). Product innovation processes in small firms: Combining entrepreneurial effectuation and managerial causation. Journal of Product Innovation Management, 31, 616-635. Retrieved from https://doi.org/10.1111/ jpim.12117

Blauth, M., Mauer, R., \& Brettel, M. (2014). Fostering creativity in new product development through entrepreneurial decision making. Creativity and Innovation Management, 23, 495-509. Retrieved from https://doi.org/10.1111/caim.12094

Brettel, M., Mauer, R., Engelen, A., \& Küpper, D. (2012). Corporate effectuation: Entrepreneurial action and its impact on R\&D project performance. Journal of Business Venturing, 27, 167-184. Retrieved from https://doi.org/10.1016/j.jbusvent.2011.01.001

Brinckmann, J., Grichnik, D., \& Kapsa, D. (2010). Should entrepreneurs plan or just storm the castle? A meta-analysis on contextual factors impacting the business planning-performance relationship in small firms. Journal of Business Venturing, 25, 24-40. Retrieved from https://doi.org/10.1016/ j.jbusvent.2008.10.007

Briner, R. B., \& Denyer, D. (2012). Systematic review and evidence synthesis as a practice and scholarship tool. Handbook of Evidence-based Management: Companies, Classrooms and Research. pp. 112-129. Retrieved from https://doi.org/10.1093/oxfordhb/9780199763986.013.0007

Cai, L., Guo, R., Fei, Y., \& Liu, Z. (2017). Effectuation, exploratory learning and new venture performance: Evidence from China. Journal of Small Business Management, 55, 388-403. Retrieved from https://doi.org/10.1111/jsbm.12247

Chandler, G. N., DeTienne, D. R., McKelvie, A., \& Mumford, T. V. (2011). Causation and effectuation processes: a validation study. Journal of Business Venturing, 26, 375-390. Retrieved from https://doi.org/10.1016/j.jbusvent.2009.10.006

Chandra, Y. (2017). A time-based process model of international entrepreneurial opportunity evaluation. Journal of International Business Studies, 48, 423-451. Retrieved from https://doi.org/10.1057/s41267-017-0068-x

Chiles, T. H., Bluedorn, A. C., \& Gupta, V. K. (2007). Beyond creative destruction and entrepreneurial discovery: A radical Austrian approach to entrepreneurship. Organization Studies, 28, 467-493. Retrieved from https://doi.org/10.1177/0170840606067996 
Chiles, T. H., Gupta, V. K., \& Bluedorn, A. C. (2008). On Lachmannian and effectual entrepreneurship: a rejoinder to Sarasvathy and Dew (2008a). Organization Studies, 29, 247-253. Retrieved from https://doi.org/10.1177/0170840607088154

Cohen, M. D., March, J. G., \& Olsen, J. P. (1972). A garbage can model of organizational choice. Administrative Science Quarterly, 17, 1-25. Retrieved from https://doi.org/10.2307/ 2392088

Corley, K. G., \& Gioia, D. A. (2011). Building theory about theory building: What constitutes a theoretical contribution?, Academy of Management Review, 36, 12-32. Retrieved from https://doi.org/10.5465/ amr.2009.0486

Cronin, P., Ryan, F., \& Coughlan, M. (2008). Undertaking a literature review: a step-by-step approach. British Journal of Nursing, 17, 38-43. Retrieved from https://doi.org/10.12968/ bjon.2008.17.1.28059. doi: 10.12968/bjon.2008.17.1.28059.

Dacin, M. T., Dacin, P. A., \& Tracey, P. (2011). Social entrepreneurship: a critique and future directions. Organization Science, 22, 1203-1213. Retrieved from https://doi.org/10.1287/orsc.1100.0620

Daniel, E. M., Domenico, M. D., \& Sharma, S. (2014). Effectuation and home-based online business entrepreneurs. International Small Business Journal: Researching Entrepreneurship, 33, 799-823. Retrieved from https://doi.org/10.1177/0266242614534281 doi: 10.1177/0266242614534281.

De Winter, J. C., Zadpoor, A. A., \& Dodou, D. (2014). The expansion of google scholar versus web of science: a longitudinal study. Scientometrics, 98, 1547-1565. Retrieved from https://doi.org/ 10.1007/s11192-013-1089-2

Engel, Y., van Burg, E., Kleijn, E., \& Khapova, S. N. (2017). Past career in future thinking: How career management practices shape entrepreneurial decision making. Strategic Entrepreneurship Journal, 11, 122-144. Retrieved from https://doi.org/10.1002/sej.1243

Evers, N., Andersson, S., \& Hannibal, M. (2012). Stakeholders and marketing capabilities in international new ventures: Evidence from Ireland, Sweden and Denmark. Journal of International Marketing, 20, 46-71. Retrieved from https://doi.org/10.1509/jim.12.0077 doi: 10.1509/jim.12.0077.

Fayolle, A., \& Liñán, F. (2014). The future of research on entrepreneurial intentions. Journal of Business Research, 67,663-666. Retrieved from https://doi.org/10.1016/j.jbusres.2013.11.024

Ferreira, A. S. M., Loiola, E., \& Gondim, S. M. G. (2017). Motivations, business planning, and risk management: Entrepreneurship among university students. RAI Revista de Administração e Inovação, 14, 140-150. Retrieved from https://doi.org/10.1016/j.rai.2017.03.003

Fiet, J. O., Piskounov, A., \& Patel, P. C. (2005). Still searching (systematically)1 for entrepreneurial discoveries. Small Business Economics, 25, 489-504. Retrieved from https://doi.org/ 10.1007/s11187-004-2277-5

Fischer, E., \& Reuber, A. R. (2011). Social interaction via new social media: (how) can interactions on Twitter affect effectual thinking and behavior?. Journal of Business Venturing, 26, 1-18. Retrieved from https://doi.org/10.1016/j.jbusvent.2010.09.002

Fisher, G. (2012). Effectuation, causation, and bricolage: A behavioral comparison of emerging theories in entrepreneurship research. Entrepreneurship Theory and Practice, 36, 1019-1051. Retrieved from https://doi.org/10.1111/j.1540-6520.2012.00537.x

Futterer, F., Schmidt, J., \& Heidenreich, S. (2017). Effectuation or causation as the key to corporate venture success? Investigating effects of entrepreneurial behaviors on business model innovation and venture performance. Long Range Planning. Retrieved from https://doi.org/ 10.1016/j.lrp.2017.06.008

Gabrielsson, J., \& Politis, D. (2011). Career motives and entrepreneurial decision-making: Examining preferences for causal and effectual logics in the early stage of new ventures. Small Business Economics, 36, 281-298. Retrieved from https://doi.org/10.1007/s11187-009-9217-3

Gabrielsson, P., \& Gabrielsson, M. (2013). A dynamic model of growth phases and survival in international business-to-business new ventures: The moderating effect of decision-making 
INMR 17,1

logic. Industrial Marketing Management, 42, 1357-1373, Retrieved from, https://oi. org/ 10.1016/j.indmarman.2013.07.011

Galkina, T., \& Chetty, S. (2015). Effectuation and networking of internationalizing SMEs. Management International Review, 55, 647-676. Retrieved from https://doi.org/10.1007/s11575-015-0251-x

Garud, R., \& Gehman, J. (2016). Theory evaluation, entrepreneurial processes, and performativity. Academy of Management Review, 41, 544-549. Retrieved from https://doi.org/10.5465/ amr.2015.0407

Gaur, A., \& Kumar, M. (2018). A systematic approach to conducting review studies: An assessment of content analysis in 25years of IB research. Journal of World Business, 53, 280-289. Retrieved from https://doi.org/10.1016/j.jwb.2017.11.003

Ghorbel, F., \& Boujelbène, Y. (2013). A comprehensive literature review of effectuation theory from 1999 to 2011. International Journal of Entrepreneurial Venturing, 5, 168-194. Retrieved from https://doi.org/10.1504/IJEV.2013.053593

Goel, S., \& Karri, R. (2006). Entrepreneurs, effectual logic, and over-trust. Entrepreneurship Theory and Practice, 30, 477-493. Retrieved from https://doi.org/10.1111/j.1540-6520.2006.00131.x

Gough, D., Oliver, S., \& Thomas, J. (2017). An introduction to systematic reviews, 2nd ed., London: Sage Publications. ISBN 978-1-4739-2942-5.

Guo, R., Cai, L., \& Zhang, W. (2016). Effectuation and causation in new internet venture growth: the mediating effect of resource bundling strategy. Internet Research, 26, 460-483. Retrieved from https://doi.org/10.1108/IntR-01-2015-0003

Gupta, V. K., Chiles, T. H., \& McMullen, J. S. (2016). A process perspective on evaluating and conducting effectual entrepreneurship research. Academy of Management Review, 41, 540-544. Retrieved from https://doi.org/10.5465/amr.2015.0433

Haapanen, L., \& Tapio, P. (2016). Economic growth as phenomenon, institution and ideology: A qualitative content analysis of the 21st century growth critique. Journal of Cleaner Production, 112, 3492-3503. Retrieved from https://doi.org/10.1016/j.jclepro.2015.10.024

Harzing, A. W. (2011). The publish or perish book: Your guide to effective and responsible citation analysis. Melbourne, Tarma Software Research PTY Ltd, 256 pages. ISBN 978-0-98088485$0-2$.

Harzing, A. W., \& van der Wal, R. (2008). Google Scholar: The democratization of citation analysis. Ethics in Science and Environmental Politics, 8, 61-73.

Kalinic, I., Sarasvathy, S. D., \& Forza, C. (2014). Expect the unexpected: Implications of effectual logic on the internationalization process. International Business Review, 23, 635-647. Retrieved from https://doi.org/10.1016/j.ibusrev.2013.11.004

Karri, R., \& Goel, S. (2008). Effectuation and over-trust: Response to sarasvathy and dew. Entrepreneurship Theory and Practice, 32, 739-748. Retrieved from https://doi.org/10.1111/ j.1540-6520.2008.00251.x

Knight, G. A., \& Liesch, P. W. (2016). Internationalization: from incremental to born global. Journal of World Business, 51, 93-102. Retrieved from https://doi.org/10.1016/j.jwb.2015.08.011

Korsgaard, S., Berglund, H., Thrane, C., \& Blenker, P. (2016). A tale of two Kirzners: Time, uncertainty, and the "nature" of opportunities. Entrepreneurship Theory and Practice, 40, 867-889. Retrieved from https://doi.org/10.1111/etap.12151

Laine, I., \& Galkina, T. (2017). The interplay of effectuation and causation in decision making: Russian SMEs under institutional uncertainty. International Entrepreneurship and Management Journal, 13, 905-941. Retrieved from https://doi.org/10.1007/s11365-016-0423-6

Lam, W., \& Harker, M. J. (2015). Marketing and entrepreneurship: An integrated view from the entrepreneur's perspective. International Small Business Journal: Researching Entrepreneurship, 33, 321-348. Retrieved from https://doi.org/10.1177/0266242613496443 
Laskovaia, A., Shirokova, G., \& Morris, M. H. (2017). National culture, effectuation, and new venture performance: Global evidence from student entrepreneurs. Small Business Economics, 49, 687-709. Retrieved from https://doi.org/10.1007/s11187-017-9852-z

Lusch, R. F., \& Vargo, S. L. (2012). The forum on markets and marketing (FMM): advancing service-dominant logic. Marketing Theory, 12, 193-199. Retrieved from https://doi.org/10.1177/1470593111429509

Markman, G. D., Russo, M., Lumpkin, G. T., Jennings, P. D., (Dev,)., \& Mair, J. (2016). Entrepreneurship as a platform for pursuing multiple goals: A special issue on sustainability, ethics, and entrepreneurship. Journal of Management Studies, 53, 673-694. Retrieved from https://doi.org/ 10.1111/joms.12214

Martín-Martín, A., Orduna-Malea, E., Thelwall, M., \& López-Cózar, E. D. (2018). Google scholar, Web of Science, and Scopus: A systematic comparison of citations in 252 subject categories. Journal of Informetrics, 12,1160-1177. Retrieved from https://doi.org/10.1016/j.joi.2018.09.002

Matalamäki, M. J. (2017). Effectuation, an emerging theory of entrepreneurship - towards a mature stage of the development. Journal of Small Business and Enterprise Development, 24, 928-949. Retrieved from https://doi.org/10.1108/JSBED-02-2017-0030

McCaffrey, M. (2014). On the theory of entrepreneurial incentives and alertness. Entrepreneurship Theory and Practice, 38, 891-911. Retrieved from https://doi.org/10.1111/etap.12013

Mitchell, R. K., Busenitz, L. W., Bird, B., Marie Gaglio, C., McMullen, J. S., Morse, E. A., \& Smith, J. B. (2007). The central question in entrepreneurial cognition research 2007. Entrepreneurship Theory and Practice, 31, 1-27. Retrieved from https://doi.org/10.1111/j.1540-6520.2007.00161.x

Neck, H. M., \& Greene, P. G. (2011). Entrepreneurship education: Known worlds and new frontiers. Journal of Small Business Management, 49, 55-70. Retrieved from https://doi.org/10.1111/ j.1540-627X.2010.00314.x

Nemkova, E. (2017). The impact of agility on the market performance of born-global firms: An exploratory study of the 'tech city' innovation cluster. Journal of Business Research, 80, 257-265. Retrieved from https://doi.org/10.1016/j.jbusres.2017.04.017

Nielsen, S. L., \& Lassen, A. H. (2012). Identity in entrepreneurship effectuation theory: A supplementary framework. International Entrepreneurship and Management Journal, 8, 373-389. Retrieved from https://doi.org/10.1007/s11365-011-0180-5

Nowiński, W., \& Rialp, A. (2016). The impact of social networks on perceptions of international opportunities. Journal of Small Business Management, 54, 445-461. Retrieved from https://doi. org/10.1111/jsbm.12149

Nummela, N., Saarenketo, S., Jokela, P., \& Loane, S. (2014). Strategic Decision-Making of a born global: a comparative study from three small open economies. Management International Review, 54, 527-550. Retrieved from https://doi.org/10.1007/s11575-014-0211-x

O'Connor, G. C., \& Rice, M. P. (2013). New market creation for breakthrough innovations: Enabling and constraining mechanisms. Journal of Product Innovation Management, 30, 209-227. Retrieved from https://doi.org/10.1111/j.1540-5885.2012.00996.x

Ortega, A. M., García, M. T., \& Santos, M. V. (2017). Effectuation-causation: What happens in new product development?. Management Decision, 55, 1717-1735. Retrieved from https://doi.org/ 10.1108/MD-03-2016-0160

Packard, M. D. (2017). Where did interpretivism go in the theory of entrepreneurship?. Journal of Business Venturing, 32, 536-549. Retrieved from https://doi.org/10.1016/j. jbusvent.2017.05.004

Pawêta, E. (2016). The effectual approach in born global firms-literature review of the current state of research. Entrepreneurial Business and Economics Review, 4, 105-115.

Perry, J. T., Chandler, G. N., \& Markova, G. (2012). Entrepreneurial effectuation: A review and suggestions for future research. Entrepreneurship Theory and Practice, 36, 837-861. Retrieved from https://doi.org/10.1111/j.1540-6520.2010.00435.x 
INMR 17,1

Politis, D., Winborg, J., \& Dahlstrand, Å. L. (2012). Exploring the resource logic of student entrepreneurs. International Small Business Journal: Researching Entrepreneurship, 30, 659-683. https://doi.org/10.1177/0266242610383445

Pruthi, S. (2014). Social ties and venture creation by returnee entrepreneurs. International Business Review, 23, 1139-1152. Retrieved from https://doi.org/10.1016/j.ibusrev.2014.03.012

Read, S., Sarasvathy, S. D., Dew, N., \& Wiltbank, R. (2016). Response to arend, sarooghi, and burkemper (2015): cocreating effectual entrepreneurship research. Academy of Management Review, 41, 528-536. Retrieved from https://doi.org/10.5465/amr.2015.0180

Read, S., Song, M., \& Smit, W. (2009). A meta-analytic review of effectuation and venture performance. Journal of Business Venturing, 24, 573-587. doi: 10.1016/j.jbusvent.2008.02.005.

Reuber, A. R., Fischer, E., \& Coviello, N. (2016). Deepening the dialogue: New directions for the evolution of effectuation theory. Academy of Management Review, 41, 536-540. Retrieved from https://doi.org/10.5465/amr.2015.0217

Reymen, I. M. M. J., Andries, P., Berends, H., Mauer, R., Stephan, U., \& van Burg, E. (2015). Understanding dynamics of strategic decision making in venture creation: A process study of effectuation and causation. Strategic Entrepreneurship Journal, 9, 351-379. Retrieved from https://doi.org/10.1002/sej.1201

Sarasvathy, S. D. (2001). Causation and effectuation: Toward a theoretical shift from economic inevitability to entrepreneurial contingency. Academy of Management Review, 26, 243-263. Retrieved from https://doi.org/10.5465/AMR.2001.4378020

Sarasvathy, S. D., \& Dew, N. (2005). Entrepreneurial logics for a technology of foolishness. Scandinavian Journal of Management, 21, 385-406. Retrieved from https://doi.org/10.1016/j. scaman.2005.09.009

Sarasvathy, S. D., \& Dew, N. (2008a). Is effectuation Lachmannian? A response to Chiles, Bluedorn, and Gupta (2007). Organization Studies, 29, 239-245. Retrieved from https://doi.org/10.1177/0170840607088153

Sarasvathy, S. D., \& Dew, N. (2008b). Effectuation and over-trust: Debating Goel and Karri. Entrepreneurship Theory and Practice, 32, 727-737. Retrieved from https://doi.org/10.1111/ j.1540-6520.2008.00250.x

Sarasvathy, S., Kumar, K., York, J.G., \& Bhagavatula, S. (2014). An effectual approach to international entrepreneurship: overlaps, challenges, and provocative possibilities. Entrepreneurship Theory and Practice, 38, 71-93.

Selden, P. D., \& Fletcher, D. E. (2015). The entrepreneurial journey as an emergent hierarchical system of artifact-creating processes. Journal of Business Venturing, 30, 603-615. Retrieved from https://doi.org/10.1016/j.jbusvent.2014.09.002

Sharma, P., \& Salvato, C. (2011). Commentary: Exploiting and exploring new opportunities over life cycle stages of family firms. Entrepreneurship Theory and Practice, 35, 1199-1205. Retrieved from https://doi.org/10.1111/j.1540-6520.2011.00498.x

Sieger, P., Gruber, M., Fauchart, E., \& Zellweger, T. (2016). Measuring the social identity of entrepreneurs: Scale development and international validation. Journal of Business Venturing, 31, 542-572. Retrieved from https://doi.org/10.1016/j.jbusvent.2016.07.001

Smolka, K. M., Verheul, I., Burmeister-Lamp, K., \& Heugens, P. P. M. A. R. (2016). Get it together! Synergistic effects of causal and effectual decision-making logics on venture performance. Entrepreneurship Theory and Practice, 1-34. Retrieved from https://doi.org/10.1111/etap.12266

Spedale, S., \& Watson, T. J. (2014). The emergence of entrepreneurial action: At the crossroads between institutional logics and individual life-orientation. International Small Business Journal: Researching Entrepreneurship, 32, 759-776. Retrieved from https://doi.org/10.1177/0266242613480376

Steyaert, C. (2007). 'Entrepreneuring' as a conceptual attractor? A review of process theories in 20 years of entrepreneurship studies. Entrepreneurship \& Regional Development, 19, 453-477. Retrieved from https://doi.org/10.1080/08985620701671759 
Tranfield, D., Denyer, D., \& Smart, P. (2003). Towards a methodology for developing evidenceInformed management knowledge by means of systematic review. British Journal of Management, 14, 207-222. Retrieved from https://doi.org/10.1111/1467-8551.00375

Velu, C., \& Jacob, A. (2016). Business model innovation and owner-managers: The moderating role of competition. R\&D Management, 46, 451-463. Retrieved from https://doi.org/10.1111/ radm. 12095

Watson, T. J. (2013). Entrepreneurial action and the Euro-American social science tradition: Pragmatism, realism and looking beyond 'the Entrepreneur'. Entrepreneurship \& Regional Development, 25, 16-33. Retrieved from https://doi.org/10.1080/08985626.2012.754267

Weick, K. E. (1995). Sensemaking in organizations, London: Sage Publications.

Werhahn, D., Mauer, R., Flatten, T. C., \& Brettel, M. (2015). Validating effectual orientation as strategic direction in the corporate context. European Management Journal, 33, 305-313. Retrieved from https://doi.org/10.1016/j.emj.2015.03.002

Whetten, D. A. (1989). What constitutes a theoretical contribution?, Academy of Management Review, 14, 490-495. Retrieved from https://doi.org/10.5465/amr.1989.4308371

Wiltbank, R., Read, S., Dew, N., \& Sarasvathy, S. D. (2009). Prediction and control under uncertainty: Outcomes in angel investing. Journal of Business Venturing, 24, 116-133. Retrieved from https://doi.org/10.1016/j.jbusvent.2007.11.004

Yang, M., \& Gabrielsson, P. (2017). Entrepreneurial marketing of international high-tech business-tobusiness new ventures: A decision-making process perspective. Industrial Marketing Management, 64, 147-160. Retrieved from https://doi.org/10.1016/j.indmarman.2017.01.007

York, J. G., O'Neil, I., \& Sarasvathy, S. D. (2016). Exploring environmental entrepreneurship: Identity coupling, venture goals, and stakeholder incentives. Journal of Management Studies, 53, 695737. Retrieved from https://doi.org/10.1111/joms.12198

\section{Corresponding author}

Suzi Elen Ferreira Dias can be contacted at: dias.suziferreira@gmail.com

Associate Editor: Dennys Eduardo Rossetto

For instructions on how to order reprints of this article, please visit our website: 